\title{
An assessment of community pharmacists' attitudes towards professional practice in the Republic of Moldova
}

\author{
Maria CORDINA, Vladimir SAFTA, Ala CIOBANU, Nina SAUTENKOVA
}

Received (first version): $19-$ Sep-2007

Accepted: 25-Nov-2007

\begin{abstract}
${ }^{*}$
Pharmacy in Moldova is undergoing a period of transition. The professional practice is adjusting to a market-oriented economy from the previous Soviet system. The pharmaceutical sector has been liberalised giving rise to a significant increase in the number of community pharmacies. This has led to some adverse effects on the profession of pharmacy with pharmacists having considerable difficulties fulfilling their professional aspirations and possibly losing confidence in further developing their professional role.

Objective: To assess community pharmacists' attitudes towards their professional practice and to determine their perceived competence in various pharmaceutical activities.

Methods: A questionnaire which addressed managerial activities, dispensing activities, pharmaceutical care activities, inter-professional relationships, public health and competence was mailed to 600 community pharmacists who were asked to score the importance and perceived competence for each activity on a scale ranging from $0-5$. In the case of pharmaceutical care activities, pharmacists were asked to score their degree of agreement or disagreement as to whether it is the responsibility of the pharmacist to engage in specific pharmaceutical care activities.

Results: A total of 370 valid questionnaires were returned giving a response rate of $61.7 \%$.

Managerial and dispensing activities were scored the highest both in terms of perceived importance and competence. The more innovative pharmaceutical care activities scored relatively low. Overall scores relating to the importance of pharmacists engaging in public health activities appear to be the lowest of the entire questionnaire. Younger pharmacists between the ages of 22-30 obtained significantly higher scores with regards to the perceived pharmacist's responsibility in engaging in various pharmaceutical care activities. Respondents who practiced in an accredited
\end{abstract}

\footnotetext{
Maria CORDINA B.Pharm (Hons) PhD (QUB). Department of Pharmacy, University of Malta. Msida (Malta)

Vladimir SAFTA. Deputy Director. National Medicines Agency, Ministry of Health and Social Protection. Chisinau (Republic of Moldova).

Ala CIOBANU. President of the Association of

Pharmacists of the Republic of Moldova. Chisinau (Republic of Moldova)

Nina SAUTENKOVA. Manager, Pharmaceutical Policy in NIS, Health Technology and Pharmaceutics. World Health Organisation, Regional Office for Europe. Copenhagen (Denmark)
}

pharmacy scored higher in the majority of questions.

Conclusion: Pharmacists in Moldova appear to be deeply rooted in the traditional approach to the practice of pharmacy pertaining mainly to distributive practice model and are somewhat distant from the other models of practice such as pharmaceutical care, drug information and self-care.

Keywords: Community Pharmacy Services. Professional Practice. Moldova.

\section{EVALUACIÓN DE LAS ACTITUDES DE LOS FARMACÉUTICOS COMUNITARIOS HACIA EL EJERCICIO PROFESIONAL EN LA REPUBLICA DE MOLDOVA}

\section{RESUMEN}

La farmacia en Moldova está sufriendo un periodo de transición. El ejercicio profesional se está ajustando a una economía de mercado desde el anterior sistema soviético. El sector farmacéutico se ha liberalizado dando lugar a un significativo incremento en el número de farmacias comunitarias. Esto ha producido algunos efectos adversos sobre la profesión farmacéutica que tiene dificultades de cumplir sus aspiraciones profesionales y posiblemente perdiendo confianza en el futuro desarrollo de su papel profesional. Objetivo: Evaluar las actitudes de los farmacéuticos comunitarios hacia su ejercicio profesional y determinar su percepción de competencia en varias actividades farmacéuticas.

Métodos: Se envió un cuestionario a 600 farmacéuticos comunitarios a los que se pedía que puntuasen la importancia y la competencia percibida con valores de 0-5 para cada una de las actividades: gestión, dispensación, atención farmacéutica, relaciones inter-profesionales, y salud pública. En las actividades de atención farmacéutica, se pidió a los farmacéuticos que puntuasen su grado de acuerdo o desacuerdo sobre si es responsabilidad del farmacéutico involucrarse en actividades específicas de atención farmacéutica. Resultados: Se recibieron 370 cuestionarios válidos con una tasa de respuesta del $61 \%$. Las actividades de gestión y de dispensación fueron puntuadas las más altas tanto en términos de importancia percibida como de competencia. Las más innovadoras actividades de atención farmacéutica puntuaron relativamente bajas. Las puntuaciones totales relativas a la importancia de que los farmacéuticos se involucren en actividades de salud 
pública aparecieron en el lugar más bajo del cuestionario. Los farmacéuticos jóvenes, entre 2230 años, obtuvieron puntuaciones

significativamente más altas sobre la percepción de la responsabilidad del farmacéutico de involucrarse en varias actividades de atención farmacéutica. Los respondentes que ejercían en una farmacia acreditada puntuaron más alta en la mayoría de las preguntas.

Conclusión: Los farmacéuticos de Moldova parecían estar profundamente enraizados en la aproximación tradicional del ejercicio de la farmacia, perteneciendo principalmente al modelo de ejercicio distributivo y, de algún modo, distantes de otros modelos de ejercicio como la atención farmacéutica, la información sobre medicamentos y el auto-cuidado.

Palabras clave: Servicios de farmacias comunitarias. Ejercicio profesional. Moldova.

\section{INTRODUCTION}

The Republic of Moldova is a landlocked country, with about three million inhabitants, in Eastern Europe, located between Romania to the west and Ukraine to the north, east and south. Moldova was formerly part of the Soviet Union and has been a Newly Independent State (NIS) since 1991. It is a densely populated country with about $54 \%$ of the population living in rural areas. Moldova has an economy which is in transition and is thus undergoing reform in various sectors including the health and social sectors. ${ }^{1}$

Initially following independence Moldova inherited the Semashko health care model from the former Soviet Union, having a highly centralized structure with key decision making and planning taking place in the capital. ${ }^{2}$ The country's health care system has since been decentralised into a regional (judet) system and since 1993 pharmacies were allowed to become privatised with most being concentrated in towns leaving a number of rural settlements with no/limited access to pharmacy. ${ }^{3}$ Currently there is a mixed system of state and privately owned pharmacies. ${ }^{2}$ Official data indicates that there are about 1000 pharmacies putting the pharmacy to population ratio at 1:3000. Pharmacies are licensed and regulated by The Ministry of Health through the National Medicines Agency.

The large scale privatization was set in motion following both an economic collapse and a breakdown in the national prescription system, which led to the state having difficulties in ensuring an adequate and regulated drug supply. The privatization system was meant to address these shortcomings. ${ }^{2}$ This wide spread liberalisation, has however, led pharmacy to be increasingly seen as a part of the commercial sector rather than a part of a professional system within healthcare. In order to improve access to medicines in rural areas, pharmacy outlets - branches of licensed pharmacies- staffed by pharmacy assistants were granted permission to operate. In addition local hospitals were allowed to open pharmacy outlets, which are, however, staffed by any available health care worker in the area and not by pharmacists or pharmacy assistants. The privatization of this sector has led to a situation whereby medical doctors have been allowed to purchase pharmacies, usually in the clinic or hospital where they work leading to a situation of conflict of interest where expensive or inappropriate drugs are prescribed to increase the pharmacies' profit margins at the detriment of the patient. $^{2}$

While theoretically under the Semashko model patients received unlimited free services, the provision of modern pharmaceuticals was very limited. Currently the spectrum of medicines available has increased, however, access is still a problem due to costs of drugs placing specific patient groups such those with chronic diseases in a difficult situation as they may not afford to purchase their medication leading to inadequate control of their condition. The World Health Organization through the Special Project for Pharmaceuticals in NIS has drawn up and supported the use of a National Essential Drugs List to encourage rational use of drugs in Moldova. ${ }^{4}$

As part of the reform in the health sector, under the law on Evaluation and Accreditation in Health Care (2001) a process of accreditation for pharmacies has been set in motion. Pharmacies in Moldova need to be accredited in order to be eligible to enter an agreement with The National Health Insurance Company for drug reimbursement. The accreditation of pharmacies falls under the responsibility of the National Accreditation Council which sets the required standards based on Good Pharmacy Practice Guidelines (GPP) issued by WHO. ${ }^{5}$ At present 338 pharmacies have been accredited by the National Accreditation Council. This is envisaged as being a very constructive step which may lead to further positive developments in community pharmacy.

There are currently about 3000 pharmacists in Moldova, approximately three quarters of whom are women. Students receive their pharmacy education at the University of Medicine and Pharmacy in Chisinau where they follow a 5 year university course which precedes a 2 year residency programme. Previously the training was modelled under the Soviet system with the course having a very strong emphasis on chemistry. ${ }^{6}$ However as part of the reform in education taking place since 1991 the aim is for the training to be in line with European Union norms. ${ }^{7}$ Since the late 1990's the pharmacy curriculum has been revised and now includes more practice based subjects such as pharmacotherapy and more recently topics related to social pharmacy and pharmaceutical care have been included.

The problems in the pharmaceutical sector during the period of transition have adversely affected the profession of pharmacy with pharmacists having significant difficulties fulfilling their professional aspirations and possibly losing confidence in further 
developing their professional role. The aim of the study was therefore to assess community pharmacists' attitudes towards their professional practice and to determine their perceived competence in various pharmaceutical activities

\section{METHODS}

A questionnaire was mailed to 600 community pharmacists (one in every 5). These pharmacists were randomly selected from a population of 3000 pharmacists. Pharmacists were given a deadline by which to return the completed questionnaires. The questionnaire consisted of 37 questions divided into 6 sections which addressed various aspects of practice. The questionnaire was translated into Romanian and back translated into English by a third party. The sections addressed were managerial activities, dispensing activities, pharmaceutical care activities, inter-professional relationships, public health and competence. For each of the above areas pharmacists were asked to score, on a scale from $0-5 \quad(1=$ not important, $5=$ extremely important) the perceived importance of each activity, they were also asked to separately score their perceived competence $(0=$ not competent, $5=$ extremely competent), in performing each activity. In the case of questions related to pharmaceutical care activities, which have been adapted from a Odedina and Segal ${ }^{8}$, pharmacists were asked to score their degree of agreement or disagreement $(0=$ strongly disagree, $5=$ strongly agree) as to whether it is the responsibility of the pharmacists to engage in specific pharmaceutical care activities rather than the perceived importance of each activity. In addition respondents were also asked to provide the following demographic information: gender, age, years' in practice and if they practiced in an accredited pharmacy. The questionnaire was initially piloted on 15 pharmacists through the Association of Pharmacists of the Republic of Moldova. They commented on relevance, clarity and ease of understanding of questions. These comments were taken into consideration in the final draft of the Romanian version.

The data was gathered over a 3 month period between December 2006 and February 2007. Data was entered into to SPSS and analysed using Mann-Whitney U tests, Kruskal Wallis. Spearman's rho correlation was also used.

A $p$ value of $<0.05$ was considered statistically significant.

\section{RESULTS}

A total of 370 valid questionnaires were returned. A further 16 questionnaires were returned, however these were considered to be invalid due to the extensive amount of missing data. A response rate of $61.7 \%$ was thus achieved. The demographic characteristics of the respondents are shown in Table 1.
The mean scores obtained for managerial and dispensing activities both in terms of perceived importance and competence (Table 2) rank at the higher end of the scale. Respondents' scores relating to the pharmacists responsibility to engage in pharmaceutical care activities presented in Table 3 , appear to be lower, with the ones receiving a mean score above 4 being the traditional pharmacist activities. The more innovative pharmaceutical care activities scored the lowest both in terms of perceived pharmacist responsibility as well as in terms on competence. Overall scores relating to the importance of pharmacists engaging in public health activities (Table 5) appear to be the lowest of the entire questionnaire; this being perceived by respondents as being the least important activity of the pharmacist. It is also the area where pharmacists felt the least competent especially when engaging in health screening activities registering a mean perceived competence score of $2.9(S D=1.78)$.

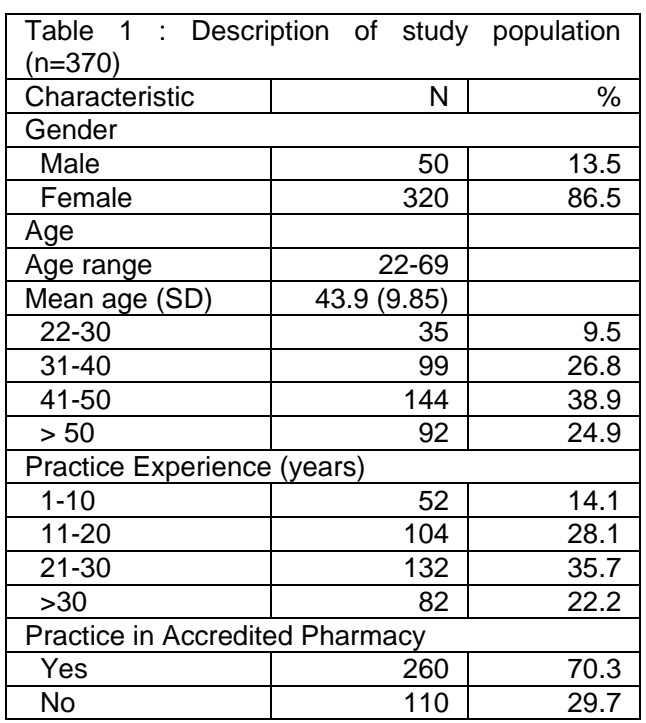

There was a significant $(p<0.01)$ positive correlation between all questions relating to perceived importance/perceived pharmacist responsibility (in the case of pharmaceutical care activities) and perceived competence, indicating that one parameter has a direct influence on the other.

Males scored higher than females in $90 \%$ of the questionnaire, obtaining significantly higher scores in terms of perceived competence related to: ensuring that medicines are of good quality, planning and implementing strategies to resolve drug related problems $(\mathrm{p}<0.05)$; consulting with other pharmacists about specific patient related problems $(p<0.05)$; providing general health information to patients $(\mathrm{p}<0.05)$; providing updated, unbiased medicines information to patients and doctors $(p<0.01)$; Males also placed significantly higher importance than females on: providing updated, unbiased medicines information to patients and doctors $(p<0.05)$ and having access to appropriate informational services to enable efficient practice $(p<0.05)$. 


\begin{tabular}{|c|c|c|c|}
\hline Managerial activity & $\begin{array}{l}\text { Perceived } \\
\text { Importance* } \\
\text { Mean (SD) }\end{array}$ & $\begin{array}{l}\text { Perceived } \\
\text { Competence* } \\
\text { Mean (SD) }\end{array}$ & $\begin{array}{l}\text { Correlation between } \\
\text { importance \& competence }\end{array}$ \\
\hline $\begin{array}{l}\text { Ensuring pharmacy is well supplied with } \\
\text { medicines }\end{array}$ & $4.7(0.59)$ & $4.3(1.32)$ & $r=0.247, p<0.01$ \\
\hline Ensuring that medicines are of good quality & $4.7(0.60)$ & $4.2(1.41)$ & $r=0.383, p<0.01$ \\
\hline $\begin{array}{l}\text { Ensuring appropriate storage conditions for } \\
\text { medicines }\end{array}$ & $4.6(0.63)$ & $4.3(1.18)$ & $r=0.484, p<0.01$ \\
\hline $\begin{array}{l}\text { Ensuring that the environment within the } \\
\text { pharmacy reflects a professional setting both } \\
\text { in terms of staff and facilities }\end{array}$ & $4.5(0.72)$ & $4.2(1.14)$ & $r=0.511, p<0.01$ \\
\hline $\begin{array}{l}\text { Ensuring that the pharmacy has a private } \\
\text { area where the pharmacist can have a } \\
\text { confidential conversation with the patient }\end{array}$ & $4.0(1.18)$ & $3.7(1.58)$ & $r=0.381, p<0.01$ \\
\hline $\begin{array}{l}\text { Ensuring that the pharmacy makes a good } \\
\text { profit }\end{array}$ & $4.3(0.90)$ & $3.8(1.39)$ & $r=0.559, p<0.01$ \\
\hline \multicolumn{4}{|l|}{ Dispensing activity } \\
\hline $\begin{array}{l}\text { Dispensing a prescription item only against } \\
\text { prescription }\end{array}$ & $4.2(1.05)$ & $4.2(1.26)$ & $r=0.439, p<0.01$ \\
\hline Assessing that a prescription is a legally valid & $4.6(0.70)$ & $4.3(1.26)$ & $r=0.555, p<0.01$ \\
\hline $\begin{array}{l}\text { Assessing the pharmaceutical and } \\
\text { pharmacological aspects e.g. appropriate } \\
\text { dosage form, dose, frequency }\end{array}$ & $4.6(0.67)$ & $4.2(1.31)$ & $r=0.467, p<0.01$ \\
\hline $\begin{array}{l}\text { Assessing appropriateness of medication for } \\
\text { the individual e.g. checking for contra- } \\
\text { indication, interactions ect. }\end{array}$ & $4.4(0.81)$ & $4.1(1.27)$ & $r=0.553, p<0.01$ \\
\hline $\begin{array}{l}\text { Assessing that the medication it the most } \\
\text { economically viable for the patient }\end{array}$ & $4.2(0.91)$ & $4.0(1.23)$ & $r=0.413, p<0.01$ \\
\hline $\begin{array}{l}\text { Double checking the prescription before } \\
\text { dispensing }\end{array}$ & $4.5(0.94)$ & $4.3(1.26)$ & $r=0.675, p<0.01$ \\
\hline $\begin{array}{l}\text { Providing the patient with information } \\
\text { regarding the medicine }\end{array}$ & $4.6(0.74)$ & $4.4(1.11)$ & $r=0.449, p<0.01$ \\
\hline $\begin{array}{l}\text { Explaining to the patient how to take the } \\
\text { medication and for how long }\end{array}$ & $4.7(0.69)$ & $4.4(1.16)$ & $r=0.547, p<0.01$ \\
\hline $\begin{array}{l}\text { Explaining the possible side effects to the } \\
\text { patient }\end{array}$ & $4.3(0.96)$ & $4.2(1.20)$ & $r=0.535, p<0.01$ \\
\hline $\begin{array}{l}\text { Ensuring that the patient has understood the } \\
\text { information provided }\end{array}$ & $4.4(0.91)$ & $4.2(1.16)$ & $r=0.551, p<0.01$ \\
\hline${ }^{*}(0=$ low; 5=high $)$ & & & \\
\hline
\end{tabular}

\begin{tabular}{|l|c|c|c|}
\hline \multicolumn{1}{|c|}{ Table 3: Respondents' mean scores for pharmaceutical care activities } \\
\hline $\begin{array}{l}\text { Pssess patients' health-related problem } \\
\text { and medication requirements }\end{array}$ & $\begin{array}{c}\text { Perceived Pharmacist } \\
\text { Responsibility } \\
\text { Mean (SD) }\end{array}$ & $\begin{array}{c}\text { Perceived } \\
\text { Competence } \\
\text { Mean (SD) }\end{array}$ & $\begin{array}{c}\text { Correlation between } \\
\text { responsibility \& } \\
\text { competence }\end{array}$ \\
\hline $\begin{array}{l}\text { Keep information (records) about the } \\
\text { patients' medical condition/s, medication } \\
\text { and progress }\end{array}$ & $3.9(1.16)$ & $3.8(1.32)$ & $\mathrm{r}=0.534, \mathrm{p}<0.01$ \\
\hline $\begin{array}{l}\text { Be actively involved in the selection of the } \\
\text { most appropriate medication for the patient }\end{array}$ & $3.9(1.30)$ & $3.3(1.54)$ & $\mathrm{r}=0.531, \mathrm{p}<0.01$ \\
\hline $\begin{array}{l}\text { Explain to patients what they should } \\
\text { expect from their medicine }\end{array}$ & $4.2(0.95)$ & $3.7(1.37)$ & $\mathrm{r}=0.576, \mathrm{p}<0.01$ \\
\hline $\begin{array}{l}\text { Monitor patients' progress after dispensing } \\
\text { the medicine }\end{array}$ & $3.4(1.50)$ & $3.2(1.60)$ & $\mathrm{r}=0.552, \mathrm{p}<0.01$ \\
\hline $\begin{array}{l}\text { Attempt to identify any drug-related } \\
\text { problem patients may be experiencing }\end{array}$ & $3.8(1.26)$ & $3.5(1.42)$ & $\mathrm{r}=0.492, \mathrm{p}<0.01$ \\
\hline $\begin{array}{l}\text { Plan and implement a strategy to resolve } \\
\text { these drug-related problems }\end{array}$ & $3.6(1.40)$ & $3.3(1.58)$ & $\mathrm{r}=0.535, \mathrm{p}<0.01$ \\
\hline $\begin{array}{l}\text { Have a procedure in place to evaluate the } \\
\text { progress and outcomes of treatment }\end{array}$ & $3.6(1.39)$ & $3.3(1.56)$ & $\mathrm{r}=0.547, \mathrm{p}<0.01$ \\
\hline $\begin{array}{l}\text { Communicate the patient's progress on } \\
\text { their drug therapy to their doctor }\end{array}$ & $3.6(1.50)$ & $3.3(1.56)$ & $\mathrm{r}=0.547, \mathrm{p}<0.01$ \\
\hline $\begin{array}{l}\text { Refer the patient to the doctor when } \\
\text { necessary }\end{array}$ & $4.6(0.77)$ & $4.4(1.10)$ & $\mathrm{r}=0.583, \mathrm{p}<0.01$ \\
\hline $\begin{array}{l}\text { Recording all professional activities in a } \\
\text { manner that allows access to } \\
\text { comprehensive information }\end{array}$ & $4.2(1.10)$ & $3.7(1.45)$ & $\mathrm{r}=0.531 \mathrm{p}<0.01$ \\
\hline $\begin{array}{l}* \text { (0=strongly disagree; } 5=\text { strongly agree) } \\
* * \text { (0=low; } 5=h i g h)\end{array}$ & & \\
\hline
\end{tabular}




\begin{tabular}{|l|c|c|c|}
\hline \multicolumn{1}{|c|}{ Table 4 : Respondents' mean scores for inter/intra-professional relationships } \\
\hline & $\begin{array}{c}\text { Perceived } \\
\text { Importance* } \\
\text { Mean (SD) }\end{array}$ & $\begin{array}{c}\text { Perceived } \\
\text { Competence* } \\
\text { Mean (SD) }\end{array}$ & $\begin{array}{c}\text { Correlation between } \\
\text { importance \& competence }\end{array}$ \\
\hline $\begin{array}{l}\text { Establishing a professional relationship } \\
\text { with doctors to enable joint therapeutic } \\
\text { management of patient }\end{array}$ & $4.3(0.97)$ & $3.9(1.24)$ & $\mathrm{r}=0.478, \mathrm{p}<0.01$ \\
\hline $\begin{array}{l}\text { Consulting with other pharmacists about } \\
\text { specific patient problems }\end{array}$ & $4.1(1.19)$ & $4.0(1.37)$ & $\mathrm{r}=0.619 \mathrm{p}<0.01$ \\
\hline $\begin{array}{l}\text { Establishing communication with other } \\
\text { healthcare professionals or agencies to } \\
\text { refer patients with social problems }\end{array}$ & $3.9(1.16)$ & $3.6(1.39)$ & $\mathrm{r}=0.521, \mathrm{p}<0.01$ \\
\hline${ }^{*}(0=$ low; 5=high) & \multicolumn{3}{|l}{} \\
\hline
\end{tabular}

\begin{tabular}{|l|c|c|c|}
\hline \multicolumn{1}{|c|}{ Aable 5 : Respondents' mean scores for public health activities } \\
\hline & $\begin{array}{c}\text { Perceived } \\
\text { Importance } \\
\text { Mean (SD) }\end{array}$ & $\begin{array}{c}\text { Perceived } \\
\text { Competence } \\
\text { Mean (SD) }\end{array}$ & $\begin{array}{c}\text { Correlation between } \\
\text { importance \& competence }\end{array}$ \\
\hline $\begin{array}{l}\text { Be active in providing general health information } \\
\text { to patients }\end{array}$ & $3.7(1.38)$ & $3.6(1.37)$ & $\mathrm{r}=0.520, \mathrm{p}<0.01$ \\
\hline $\begin{array}{l}\text { Provide update, unbiased information medicines } \\
\text { information to patients and doctors }\end{array}$ & $3.8(1.46)$ & $3.7(1.44)$ & $\mathrm{r}=0.552, \mathrm{p}<0.01$ \\
\hline Engage in health screening activities & $3.0(1.79)$ & $2.9(1.78)$ & $\mathrm{r}=0.691, \mathrm{p}<0.01$ \\
\hline Engage in health promotion activities & $3.7(1.46)$ & $3.5(1.47)$ & $\mathrm{r}=0.554, \mathrm{p}<0.01$ \\
\hline${ }^{*}(0=$ =low; 5=high) & & \\
\hline
\end{tabular}

\begin{tabular}{|l|c|}
\hline \multicolumn{1}{|c|}{ Table 6: Respondents' mean scores for maintenance of competence } \\
\hline \multicolumn{1}{|c|}{ Activity } & $\begin{array}{c}\text { Perceived Importance } \\
\text { Mean (SD) }\end{array}$ \\
\hline Have access to appropriate informational services to enable efficient practice & $4.1(1.20)$ \\
\hline $\begin{array}{l}\text { Regularly participate in high quality continuing education programmes to enable } \\
\text { competency improvement }\end{array}$ & $4.3(1.17)$ \\
\hline Engaging in self-assessment of competence and professional activities & $4.2(1.26)$ \\
\hline${ }^{*}(0=$ low; 5=high) & \\
\hline
\end{tabular}

\begin{tabular}{|c|c|}
\hline \multicolumn{2}{|l|}{ Perceived importance placed on activities } \\
\hline Ensuring appropriate storage conditions for medicines & $\mathrm{p}<0.001$ \\
\hline $\begin{array}{l}\text { Ensuring that the environment within the pharmacy reflects a professional setting both in terms of staff } \\
\text { and facilities }\end{array}$ & $\mathrm{p}<0.001$ \\
\hline Ensuring that the pharmacy makes a good profit & $\mathrm{p}<0.05$ \\
\hline Assessing that a prescription is a legally valid & $\mathrm{p}<0.01$ \\
\hline Assessing the pharmaceutical and pharmacological aspects of a prescription & $\mathrm{p}<0.001$ \\
\hline Assessing appropriateness of medication for the individual & $\mathrm{p}<0.01$ \\
\hline Double checking the prescription before dispensing & $\mathrm{p}<0.05$ \\
\hline Explaining to the patient how to take the medication and for how long & $p<0.05$ \\
\hline Ensuring that the patient has understood the information provided & $\mathrm{p}<0.001$ \\
\hline Establishing a professional relationship with doctors to enable joint therapeutic management of patient & $\mathrm{p}<0.01$ \\
\hline Consulting with other pharmacists about specific patient problems & $\mathrm{p}<0.001$ \\
\hline $\begin{array}{l}\text { Establishing communication with other healthcare professionals or agencies to refer patients with social } \\
\text { problems }\end{array}$ & $p<0.001$ \\
\hline Have access to appropriate informational services to enable efficient practice & $\mathrm{p}<0.05$ \\
\hline Engaging in self-assessment of competence and professional activities & $\mathrm{p}<0.01$ \\
\hline \multicolumn{2}{|l|}{ Perceived pharmacist responsibility in performing pharmaceutical care activities } \\
\hline Be actively involved in the selection of the most appropriate medication for the patient & $p<0.05$ \\
\hline Explain to patients what they should expect from their medicine & $p<0.05$ \\
\hline Attempt to identify any drug-related problem patients may be experiencing & $p<0.05$ \\
\hline Refer the patient to the doctor when necessary & $\mathrm{p}<0.01$ \\
\hline Recording all professional activities in a manner that allows access to comprehensive information & $p<0.01$ \\
\hline \multicolumn{2}{|l|}{ Perceived competence } \\
\hline Assessing that a prescription is a legally valid & $\mathrm{p}<0.01$ \\
\hline Refer the patient to the doctor when necessary & $p<0.001$ \\
\hline
\end{tabular}

Pharmacists within the younger age group of 22-30 years of age obtained significantly lower scores when compared to other age groups in terms of perceived competence in: assessing the appropriateness of the medication for the individual $(p<0.01)$; explaining to patients what they should expect from their medication $(p<0.05)$; monitoring the patient's progress after dispensing the medication $(p<0.001)$; establishing professional relationships with doctors to enable joint therapeutic management of patients $(p<0.01)$ and in providing updated unbiased medicines information to patients 
and other doctors $(\mathrm{p}<0.01)$; However, these younger pharmacists obtained significantly higher scores as compared to other age groups when indicating the perceived pharmacist's responsibility in engaging in the following pharmaceutical care activities: assessing patients' health-related problems and medication requirements $(p<0.01)$; monitoring the patient's progress after dispensing the medicine $(p<0.05)$; planning and implementing a strategy to resolve drug related problems; recording all professional activities in a manner that allows access to comprehensive information $(p<0.05)$. This age group also placed significantly higher importance with regards to the pharmacist engaging in health screening activities $(p<0.05)$. Pharmacists over the age of 50 scored significantly higher than other age groups with regards to the pharmacists perceived responsibility to have a procedure in place to evaluate the progress and outcomes of treatment $(p<0.01)$ and communicate the patient's progress on their drug therapy to their doctor $(p<0.01)$

Pharmacists practicing in an accredited pharmacy tended to score higher with $100 \%$ achieving higher scores in questions relating to perceived importance/ perceived pharmacist responsibility for pharmaceutical care activities and $53 \%$ scoring higher in terms of perceived competence. Accredited pharmacy pharmacists obtained significantly higher scores in activities shown in Table 7.

\section{DISCUSSION}

The results obtained from this study are interesting and provide an insight into pharmacists' perceptions of their professional practice. There are a number of trends which are evident, some of which are not surprising, while others are rather worthy of note.

Respondents assigned relatively high scores to activities relating to pharmacy management and dispensing, both in terms of perceived importance and perceived competence, indicating that they feel relatively comfortable and competent to conduct these activities. This is not unexpected since these activities are associated with the more traditional functions of pharmacists. In fact the highest scores of the entire questionnaire (4.7) were assigned to the activities of ensuring a pharmacy is well supplied with medicines, ensuring that the medicines are of good quality and explaining to the patient how to take the medication and for how long. These activities form the backbone of the profession. They are mainly related to access and supply of medicines and are well engrained in pharmacists due to both training and tradition.

In answering questions relating to pharmaceutical care, i.e. to what degree respondents perceived the activities listed to be the responsibility of the pharmacist, the scores were lower, most being between scores of 3-4. The lowest (3.4) relating to keeping patient records and monitoring patient's progress after dispensing. Perceived competence in conducting pharmaceutical care activities was also lower than the more traditional activities. It appears that respondents are not fully convinced that pharmaceutical care activities are the responsibility of the pharmacist and are still somewhat distant from the concept of the pharmacist as a provider of patient care.

When looking at the results in the light of the Total Pharmacy Care model for pharmacy practice proposed by Holland and $\mathrm{Nimmo}^{9}$, it appears that respondents identify mainly with the distributive practice model and are rather distant from the pharmaceutical care practice model, which includes the tasks of assuming responsibility, on the patient care team, for modifying or dispensing, recommending, monitoring and evaluating a patient's pharmacotherapy, to ensure the outcomes of the pharmacotherapy provided.

When addressing inter/intra professional relationships, the results are reflective of the possible perceived barriers to establishing such relationships in practice. In Moldova there is no structured approach to team work in patient care. The interaction between pharmacists and doctors varies and is dependent on the individuals involved. In the minority of cases professional relationships are good and patient oriented, with communication mainly taking place over the phone. However, in general, this type of inter-professional relationship is somewhat strained and has been identified as a priority area for improvement by the Association of Pharmacists. The concept that a team based approach to patient care is necessary for better patient outcomes is well established, in general health care management. Barriers to establishing a team based approach are well documented in the international literature and present an ongoing struggle. $^{10-12}$

Although $\mathrm{WHO}$ is supporting the concept of rational drug use and Moldova has established a National Drug List, a National Formulary and standard treatment guidelines have been developed, many doctors do not follow these principles and polypharmacy, over prescribing and prescribing of branded products is widespread. It is therefore essential for pharmacists to work on developing good inter-professional relationships in order to be in a better position to enhance the appropriate use of medicines. In order to influence prescribing as recommended by GPP ${ }^{5}$ and manage patients' drug therapy, pharmacists also need to identify more strongly with the pharmaceutical care practice model described above.

Public health activities received the lowest scores of the entire questionnaire both in terms of perceived importance and competence. This appears to be the weakest of all professional activities. These activities fall within the drug information practice model ${ }^{9}$; a model which appears to be the most alien to respondents. Apparently pharmacists' roles in health promotion and disease prevention are nearly non-existent in the views of politicians/policy makers and other health care professionals in Moldova. The latter two elements have also been highlighted as priorities within the health sector reform in Moldova, however the pharmacist's involvement was not envisaged. $^{2}$ This situation does very little to 
encourage pharmacists to be more proactive in this area. Health promotion and ill health prevention are listed as the first of the four main elements of GPP and hence should be given due importance within the profession. Various studies have demonstrated the community pharmacists' contribution to health promotion and the positive effect in rural communities has also been established. ${ }^{13}$ Increased support, both in terms of education and infrastructure, should be given to pharmacists to take on increased responsibility in this area.

Competence issues received moderate scores, with hardly any variations in terms of demographics. This could be related to the fact that continuing education is mandatory in Moldova with pharmacists needing to engage in 200 hours of continuing education over a period of 5 years, a system in place since the Soviet era.

Gender appears to have exerted an influence on the results, with males obtaining higher scores than females in $90 \%$ of the questions. This is an interesting factor and may relate to females feeling less confident in relation to professional practice. It may also be related to the fact that in former Soviet times it was mainly men who held senior positions within the profession.

In terms of age, younger pharmacists appear to identify more with current trends in the practice of pharmacy such as professional activities related to the delivery of pharmaceutical care by the pharmacist. While in relation to public health activities, 'engaging in health screen activities', received the lowest score of the entire questionnaire, however, younger pharmacists scored it significantly higher. These results are very positive, encouraging and augur well for the future of the profession. They also reflect the changes occurring in the pharmacy curriculum which places increased emphasis on practice related subjects. The findings also support the concept that as the knowledge base of graduates changes and they move into practice, they will influence practice change to reflect the new knowledge base. ${ }^{14}$

The factor which appears to have had the greatest influence on the results is practicing in an accredited pharmacy as illustrated in Table 7 . Respondents who practiced in an accredited pharmacy scored higher in most questions. They placed higher importance on all professional activities illustrating that practicing in a professional environment has a positive effect on the attitude to professional practice. These findings support two criteria required for practice change suggested by Nimmo and Holland, the first being the need for an environment conducive to the desired practice and the other motivation. ${ }^{15}$ The motivational factor being present due to the prerequisite of the need for the pharmacy to be accredited for it to participate in the national reimbursement scheme.

\section{CONCLUSIONS}

Pharmacists in Moldova appear to be deeply rooted in the traditional approach to the practice of pharmacy pertaining mainly to distributive practice model and are somewhat distant from the other models of practice such as pharmaceutical care, drug information and self-care. It appears that younger pharmacists identify more with the current trends in practice implying that they would be more receptive to embracing such models of practice. Accreditation of pharmacies has had a very positive influence on the pharmacists practicing in such pharmacies as they have a better perception of professional activities placing more importance on such activities.

\section{CONFLICT OF INTEREST}

None declared.

\section{References}

1. ClA World Fact Book Moldova. https://www.cia.gov/library/publications/the-world-factbook/geos/md.html\#Econ. (Accessed 30th August 2007).

2. MacLehose L in McKee M (ed) Health Care Systems in Transition: Republic of Moldova; Copenhagen, European Observatory on Health Care Systems 2000; 4 (5)

3. United States Pharmacopoeia. http://www.usp.org/worldwide/dqi/regions/moldova.html (Accessed 30th August 2007).

4. Essential drugs in brief. Department of Essential Drugs and Medicines Policy. Health Technology and Pharmaceuticals Cluster, World Health Organization, Geneva 2002; issue 6.

5. Good pharmacy practice in community and hospital settings: annex 7 to the thirty-fifth report of the WHO Expert Committee on Specifications for Pharmaceutical Preparations. WHO technical report series no.885 Geneva, Switzerland: World Health Organisation; 1999:93-101.

6. Menabde N, Stobbelar F. The patient in focus: A strategy for pharmaceutical sector reform in Newly Independent States. World Health Organisation. Copenhagen 1998. pp13-29.

7. Tiron S, Arion V, Paiu M, Scalnii V, Satan V. Higher Education in the Republic of Moldova. Monographs on Higher Education. UNSCO-CEPES. Bucharest, 2003.

8. Odedina FT, Segal R. Behavioural pharmaceutical care scale for measuring pharmacists activities. Am J Health Syst Pharm. 1996; 3:855-65.

9. Holland RW, Nimmo CM. Transitions in pharmacy practice, part1: beyond pharmaceutical care. Am J Health-Syst Pharm. 1999;56:1758-64.

10. Cordina M, McEInay JC, Hughes CM. The importance that community pharmacists in Malta place on the introduction of pharmaceutical care. Pharm World Sci. 1999; 21:69-73.

11. Hughes $\mathrm{CM}$, McCann S. Perceived inter-professional barriers between community pharmacists and general practitioners: a qualitative assessment. Br J Gen Pract. 2003; 53;600-6. 
12. Cordina M, Nurmanbetova Nusupzhanovna F, Kulmagambetov Raikhanovich I, Sautenkova N. Pharmacy and Pharmacists' Perceptions of Pharmaceutical Care in Kazakhstan. Int J Pharm Pract. 2008;16:41-6.

13. Hourihan F, Krass I, Chen T. Rural Community Pharmacy: A Feasible site for health promotion and screening service for cardiovascular risk factors. Aust J Rural Health. 2003;11;28.

14. Developing pharmacy practice: A focus on patient care. Handbook. World Health Organization in collaboration with International Pharmaceutical Federation. 2006. WHO/PSM/PAR/2006.5.

15. Nimmo CM, Holland RW. Transitions in pharmacy practice, part 4: Can a leopard change its spots. Am J Health-Syst Pharm. 1999;56:2458-62. 